Claire L. Holeton · Florence Nédélec · Richard Sanders

Louise Brown · C. Mark Moore · David P. Stevens

Karen J. Heywood · Peter J. Statham · Cathy H. Lucas

\title{
Physiological state of phytoplankton communities in the Southwest Atlantic sector of the Southern Ocean, as measured by fast repetition rate fluorometry
}

Received: 23 November 2004/ Revised: 17 May 2005/ Accepted: 17 May 2005

(C) Springer-Verlag 2005

\begin{abstract}
The majority of the Southern Ocean is a highnutrient low-chlorophyll (HNLC) ecosystem. Localized increases in chlorophyll concentration measured in the wake of bathymetric features near South Georgia demonstrate variations in the factors governing the HNLC condition. We explore the possibility that the contrast between these areas of high-chlorophyll and surrounding HNLC areas is associated with variations in phytoplankton photophysiology. Total dissolvable iron concentrations, phytoplankton photophysiology and community structure were investigated in late April 2003 on a transect along the North Scotia Ridge $\left(53-54^{\circ} \mathrm{S}\right)$ between the Falkland Islands and South Georgia (58$33^{\circ} \mathrm{W}$ ). Total dissolvable iron concentrations suggested a benthic source of iron near South Georgia. Bulk community measurements of dark-adapted photochemical quantum efficiency $\left(F_{\mathrm{v}} / F_{\mathrm{m}}\right)$ exhibited a sharp increase to the east of $46^{\circ} \mathrm{W}$ coincident with a decrease in the functional absorption cross-section $\left(\sigma_{\mathrm{PSII}}\right)$. Phytoplankton populations east of $46^{\circ} \mathrm{W}$ thus displayed no physiological symptoms of iron or nitrate stress. Contrasting low $F_{\mathrm{v}} / F_{\mathrm{m}}$ west of $46^{\circ} \mathrm{W}$ could not be explained by variations in the macronutrients nitrate and silicic acid and may be the result of taxon specific variability in photophysiology or iron stress. We hypothesize that increased $F_{\mathrm{v}} / F_{\mathrm{m}}$ resulted from local relief from ironstress near South Georgia, east of Aurora Bank, an area previously speculated to be a "pulse point" source of
\end{abstract}

C. L. Holeton $(\bowtie) \cdot$ F. Nédélec $\cdot$ R. Sanders $\cdot$ L. Brown

C. M. Moore · P. J. Statham · C. H. Lucas

National Oceanography Centre,

Southampton, SO14 3ZH, UK

E-mail: clh302@soc.soton.ac.uk

Fax: + 44-2380-596247

D. P. Stevens

School of Mathematics, University of East Anglia,

Norwich, NR4 7TJ, UK

K. J. Heywood

School of Environmental Sciences, University of East Anglia,

Norwich, NR4 7TJ, UK iron. Our measurements provide one of the first direct physiological confirmations that iron stress is alleviated in phytoplankton populations near South Georgia.

\section{Introduction}

The importance of phytoplankton production in highnutrient low-chlorophyll (HNLC) areas to global biogeochemical cycling has been well documented (Martin 1990; Priddle et al. 1992; Sarmiento 1992; Watson et al. 2000). The Southern Ocean is of particular interest, as changes to the utilization of macronutrients through increased primary production are predicted to have the largest potential effect on carbon cycling of any HNLC area (Cooper et al. 1996).

Many hypotheses have been proposed to explain the persistence of HNLC conditions in the Southern Ocean (reviewed by Boyd 2002), including top-down control of primary production by grazing (Smetacek et al. 1990; Frost 1991), and bottom-up control by iron- (Martin 1990) or light limitation (Nelson and Smith 1991). It is well accepted that the influence of these controls varies spatially and temporally (e.g., Comiso et al. 1993; Löscher et al. 1997). Additionally, the interaction of various controls such as light and iron (Sunda and Huntsman 1997) can increase the complexity in the patchwork of controls throughout the Southern Ocean.

Iron has wide ranging direct and indirect effects on phytoplankton photophysiology as a consequence of its role in the photosynthetic and nutrient acquisition machinery of algal cells (Raven 1990). Iron-limitation causes impairment of pigment synthesis and inefficient functioning of the electron transport system, reducing the photosynthetic yield per unit of chlorophyll (Behrenfeld et al. 1996). Consequently, iron-limited cells are more susceptible to light limitation (Sunda and Huntsman 1997; Lindley 1998; Lindley and Barber 1998; Timmermans et al. 2001). 
Convincing evidence that iron limits the growth of large phytoplankton in some sectors of the Southern Ocean has been provided by both shipboard and in situ iron enrichment studies (e.g., de Baar et al. 1990; Boyd et al. 2000; Coale et al. 2004). Some regions in the otherwise HNLC Southern Ocean, including areas of shallow topography, frontal upwelling and island-based ecosystems show persistently high phytoplankton pigment levels (Sullivan et al. 1993; Blain et al. 2001; Korb and Whitehouse 2004). Blain et al. (2001) demonstrated that high concentrations of chlorophyll- $a$ are primarily driven by a release of iron from submarine topographic features in the vicinity of the Sub-Antarctic island, Kerguelen.

Recently, the regions surrounding the Sub-Antarctic island of South Georgia and the North Scotia Ridge have been of particular interest with respect to iron concentrations; there has been speculation that ridges and Sub-Antarctic islands in the Scotia Sea act as "pulse-points" for iron enrichment of surface waters (Löscher et al. 1997; Moore and Abbott 2002). In a broad-scale survey of the Scotia Sea, including the region around South Georgia, Holm-Hansen et al. (2004) found that patterns of chlorophyll- $a$ distribution had no correlation with mixed layer depth. They concluded that light availability, temperature, settling and grazing have relatively little impact on spatial variability in phytoplankton biomass of the Scotia Sea when compared to the effects of iron availability. Similarly, in a study north of South Georgia, east to west increases in primary

Fig. 1 Chart of the research area with sites of the 68 stations occupied during JR-80 in the austral summer of 2003, between April 23 and May 7. Stations on the outward leg (stations 1-19: black dashed line) are indicated with closed circles; stations on the return leg (stations 35-69: black solid line) are indicated with open circles; Western Core Box (WCB; stations 20-34) stations are shown with triangles. The mean position and orientation of the Sub-Antarctic Front (SAF; Orsi et al. 1995) and the Antarctic Polar Front (APF; Moore et al. 1999) are shown with grey lines. Variability of the western extent of the Southern ACC Front is indicated by the mean position of the front as suggested by Thorpe (2001) (thick grey line) and Orsi et al. (1995) (thin grey line). The regions separated by the fronts, Polar Frontal Zone (PFZ) and Antarctic Zone (AAZ) are indicated. Dashed grey lines indicate possible current paths as derived from model and drifter data (Thorpe et al. 2002). Isobaths are shown every $1,000 \mathrm{~m}$ productivity and changes in nutrient draw-down ratios were ascribed to greater iron availability (Korb and Whitehouse 2004). Korb and Whitehouse (2004) suggest that these changes were indicative of contrasting regimes around South Georgia: a bloom-type iron-replete population northwest of the island and an iron-limited population growing in true HNLC conditions to the northeast.

Changes in photosynthetic parameters measured by fast repetition rate (FRR) fluorometry have been widely used as a diagnostic tool for the nutrient-related changes in photosynthetic competence (i.e., efficiency) (Kolber et al. 1988; Kolber and Falkowski 1993). More specifically, decreases in dark-adapted maximum photochemical quantum efficiency $\left(F_{\mathrm{v}} / F_{\mathrm{m}}\right)$ and increases in the functional absorption cross section $\left(\sigma_{\mathrm{PSII}}\right)$ have been attributed to nitrate or iron stress in marine unicellular algae (Kolber et al. 1988; Greene et al. 1991; Boyd and Abraham 2001). However, lab (Suggett et al. 2004) and field studies (Moore et al. 2005) suggest species composition may contribute to variation in these parameters between natural populations. Therefore, comparisons of in situ $F_{\mathrm{v}} / F_{\mathrm{m}}$ and $\sigma_{\mathrm{PSII}}$ data between phytoplankton communities of mixed composition should be interpreted with caution.

In this study, we use underway FRR fluorescence measurements of bulk phytoplankton community physiology to explore whether the variability in chlorophyll- $a$ and phytoplankton production near the South Georgia shelf (Korb and Whitehouse 2004) occur in a region where iron-limitation may be alleviated, as speculated by previous studies (Löscher et al. 1997; Moore and Abbott 2002).

The study area encompasses two hydrographically distinct regions (Gordon et al. 1977; Pollard et al. 2002) (Fig. 1): the Sub-Antarctic waters east of the Sub-Antarctic Front (SAF) and west of the Antarctic Polar Front (APF) within the Polar Frontal Zone (PFZ) and the polar waters east of the APF within the Antarctic Zone (AAZ). Currents enter our study area from the south, as the eastward flow of the Antarctic Circumpolar Current (ACC) turns northward past Drake Passage (Gordon et al. 1977). Passing the Sub-Antarctic island, South Georgia, the current is variable but generally sweeps northwestward around the island, steered by the Southern ACC Front (Fig. 1) (Orsi et al. 1995; Thorpe

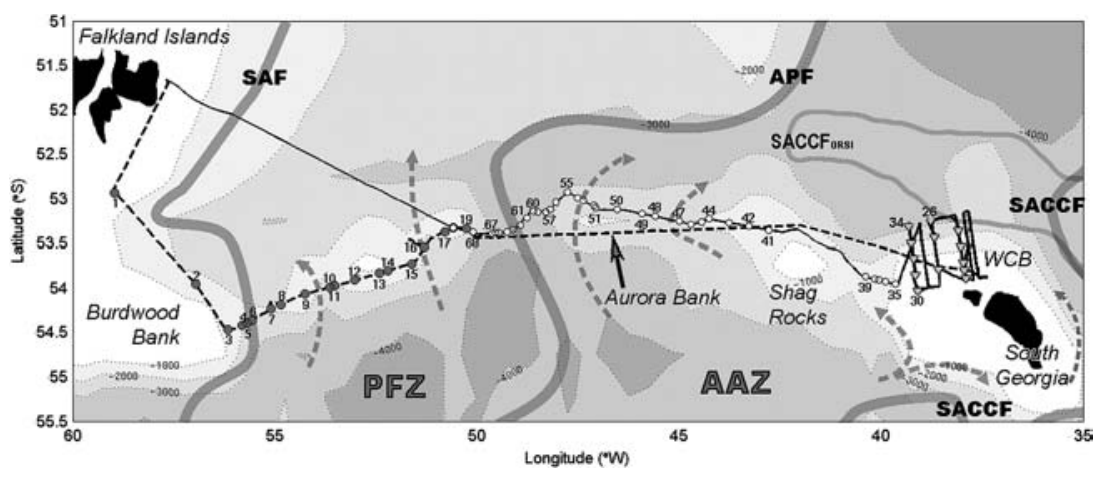


et al. 2002; Meredith et al. 2003). Model and drifter data suggests that waters along the North Scotia Ridge as far west as $45^{\circ} \mathrm{W}$ may have passed in close proximity to shallow topography on the South Georgia shelf (Thorpe et al. 2002).

\section{Methods}

Shipboard instrumentation and sampling

All fieldwork was carried out in the late austral summer, 2003, on the British Antarctic Survey vessel, RRS James Clark Ross along an east-west hydrographic transect of the North Scotia Ridge, between the Falkland Islands and South Georgia. The cruise, JR-80, was part of the North Scotia Ridge Overflow Project (funded by the NERC AFI programme, grant NER/G/S/2001/00006). The cruise consisted of an outward leg (23-26 April) from the Falkland Islands towards South Georgia, on which CTD sampling was truncated due to the onset of poor weather, an intensive study (28 April-2 May) within the British Antarctic Survey Western Core Box (WCB) and a return leg (2-7 May) from South Georgia to the Falkland Islands (Fig. 1).

Hydrographic profiles were obtained using a Sea-Bird Electronics $911+$ CTD and a Chelsea Scientific Instruments Aqua ${ }^{\text {tracka }}$ MK II fluorometer. Water was collected for chemical and biological analysis on the upcast at standard depths using $24 \times 101$ Niskin bottles. CTD profiles were used to calculate Brunt Väisälä frequency, $N^{2}$ (Gill 1981), a measure of stability, which was used to estimate the bottom of the upper mixed layer. Incident photosynthetically active radiation (PAR: $\lambda=400$ $700 \mathrm{~nm}$ ) was measured with a $2-\pi$ sensor (PAR LITE, Sci-Tec) mounted on the foremast. Euphotic depths (depth of $1 \%$ surface light) were calculated using a relationship between light attenuation and surface chlorophyll concentrations (Nelson and Smith 1991). Continuous measurements of sea surface temperature, salinity and fluorescence from the ship's uncontaminated surface water supply $(6.5 \mathrm{~m})$ were made using a Sea-Bird SBE21 thermosalinograph and Turner Designs 10-AU fluorometer, respectively. Physiological characteristics of the surface phytoplankton population were measured from the uncontaminated surface water supply using a Chelsea Scientific Instruments Fast ${ }^{\text {tracka }}$ FRR fluorometer.

\section{Chemical and biological analysis}

Samples for analysis of inorganic nutrients were drawn from Niskin bottles from all depths sampled and kept in the dark at $4^{\circ} \mathrm{C}$ until analysis, which was carried out following the methods of Sanders and Jickells (2000) within $12 \mathrm{~h}$ of sampling. Concentrations of silicic acid, phosphate and combined nitrate and nitrite (hereafter referred to as nitrate) were determined by conventional colorimetric methods using a Skalar San Plus continuous flow autoanalyser. The precision of the analyses was estimated to be $\pm 0.45, \pm 0.08$ and $\pm 1.02 \mu \mathrm{M}$ for nitrate, phosphate and silicic acid, respectively, over the duration of the cruise, based on the difference between replicate samples. Accuracy was determined over 35 measurements of Ocean Scientific International commercial standards; $10 \mu \mathrm{M}$ nitrate standard was measured as $10.08 \pm 0.60 \mu \mathrm{M}, \quad 1 \mu \mathrm{M}$ phosphate standard was measured as $0.87 \pm 0.07 \mu \mathrm{M}$ and the $10 \mu \mathrm{M}$ silicic acid standard was measured as $10.00 \pm 0.40 \mu \mathrm{M}$.

Samples for analysis of total dissolvable iron concentration $(n=21)$ were collected in acid-washed lowdensity polyethylene bottles, using a pole sampler (Sherrell and Boyle 1988) deployed while arriving on station. Care was taken to minimize contamination from the vessel itself whilst sampling and during handling steps. Unfiltered samples were stored in sealed plastic bags for return to the laboratory, where they were acidified several days before analysis with $1 \mathrm{ml}$ of concentrated quartz-distilled $\mathrm{HCl}$ per 11 of seawater.

Total dissolvable iron (TD-Fe) measurements were made using flow-injection with chemiluminescence detection using luminol to detect $\mathrm{Fe}(\mathrm{II})$ and $\mathrm{Fe}(\mathrm{III})$ in seawater, after preconcentration (Obata et al. 1993; Johnson et al. 2003). An analytical cycle consisted of preconcentration of iron onto 8-hydroxyquinoline immobilized on a Fractogel resin (Landing et al. 1986), rinsing with Milli-Q water, elution and chemiluminescent detection. The calibration was done by standard additions of iron to acidified seawater. The relationship was linear $\left(r^{2}=0.9955\right)$ and the precision ranged from 0.7 to $7.6 \%$ rsd (average $3.0 \%$ rsd). Blank and limit of detection (3sd of the blank) values were 400 and $83 \mathrm{pM}$, respectively. Accuracy of this analysis was checked using a low-iron seawater internal standard with a concentration determined at $0.99 \pm 0.17 \mathrm{nM}$. Accuracy of the system was checked with NASS-5 certified reference material (from the National Research Council of Canada) and was within the range of the certified value $3.71 \pm 0.63 \mathrm{nM}$.

Seawater samples from the ship's uncontaminated surface water supply or surface Niskin bottles $(n=45)$ were preserved using a $1 \%$ solution of Lugol's acid iodine for later examination by light microscopy. Pigment samples were collected from the same water samples by gentle filtration of seawater onto Whatman $25 \mathrm{~mm} \mathrm{GF} /$ $\mathrm{F}$ filters. The filters were stored at $-80^{\circ} \mathrm{C}$ until analysis by high performance liquid chromatography (HPLC) 9 weeks later. Pigments were extracted from frozen filters by sonication in $90 \%(\mathrm{v} / \mathrm{v})$ acetone and passed through a $0.2 \mu \mathrm{m}$ nylon membrane filter before measurement with a ThermoFinigan HPLC following the method of Barlow et al. (1993). Pigments were identified using an on-line diode array spectrophotometer and through co-elution with commercial pigment standards. All values of chlorophyll- $a$ reported in this study are derived from HPLC determination. 
Active fluorescence

Continuous bulk community measurements of active fluorescence were made using a FRR fluorometer, operated in bench-top mode with a continuous flowthrough of water from the uncontaminated surface water supply at $\sim 30 \mathrm{ml} \mathrm{s}^{-1}$. Variable fluorescence was induced using a flash protocol of 100 saturation flashes per sequence with a flash duration of $1.1 \mu \mathrm{s}$ at a $2.8 \mu \mathrm{s}$ interval. The PMT gain was set to autoranging mode. Only dark-adapted data (collected when incident PAR was less than $\left.1 \mu \mathrm{mol} \mathrm{m}{ }^{-2} \mathrm{~s}^{-1}\right)$ are presented here. Additional precautions against light contamination of the samples included blocking ambient lighting by using opaque black tubing.

Values of dark-adapted maximum photochemical quantum efficiency $\left(F_{\mathrm{v}} / F_{\mathrm{m}}\right)$ and functional absorption cross-section $\left(\sigma_{\mathrm{PSII}}\right)$ were calculated by fitting the measured saturation curves to the biophysical model of Kolber et al. (1998) using MATLAB code based on the software provided by S. Laney "v4" (Laney 2003). $F_{\mathrm{v}} /$ $F_{\mathrm{m}}$ and $\sigma_{\mathrm{PSII}}$ were averaged over $10 \mathrm{~min}$ intervals.

\section{Statistics}

To provide a measure of the differences in some of the biological and chemical characteristics between the various regions, the data from regional zones were divided into subsets with similar characteristics. Regional zones were determined according to temperature, salinity and longitude to produce the following divisions in the dataset: Polar Frontal Zone (PFZ), western Antarctic Zone (AAZw), eastern Antarctic Zone (AAZe) and areas proximal to South Georgia (SG). The division of the AAZ into east and west components was adopted to facilitate discussion of patterns in physiology that occurred within the region.

Fig. 2 Vertical density $\left(\sigma_{\theta}\right)$ section across the North Scotia Ridge compiled from CTD profiles collected during JR-80. The approximate surface position of the Sub-Antarctic Front (SAF) and Antarctic Polar Front (APF) are shown. Contours indicate isopycnals at an interval of 0.05 . Thick black line indicates the estimated depth of surface mixing (MLD); white triangles and dashed line indicate the euphotic depth estimates $\left(Z_{\mathrm{eu}}\right)$
The means of mixed layer depth, euphotic depth estimates, silicic acid, $F_{\mathrm{v}} / F_{\mathrm{m}}$ and $\sigma_{\mathrm{PSII}}$ were compared between zones by one-way ANOVA. Zones with statistically indistinguishable means were grouped into homogeneous subsets as indicated by the post-hoc procedure, Tukey's $b$ test (i.e., groupings based on statistical differences at the $5 \%$ level). The distribution of fucoxanthin/19'-hexanoyloxyfucoxanthin concentration deviated significantly from normality, thus the MannWhitney $U$-test (a non-parametric analysis) was used to determine significant differences between means.

\section{Results}

Hydrographic properties

The SAF and the APF were evident in hydrographic profiles (Fig. 2), crossing the North Scotia Ridge near Burdwood Bank and within Shag Rocks Passage (Fig. 1). The location of the surface signature of the PF during the cruise was variable, evident in the sharp gradients of surface temperature (Fig. 3), shifting from $\sim 48^{\circ} \mathrm{W}$ to $47^{\circ} \mathrm{W}$. The presence of an "eddy-like" structure (indicated as E in Fig. 3), possibly a frontal meander, was apparent in the hydrographic properties measured on the return leg. The temperature and salinity within the structure suggested the water originated in the PFZ.

At most stations along the North Scotia Ridge, the mixed layer depth (MLD) was relatively deep (80 $\mathrm{m}$ on average) (Fig. 2). MLD at the WCB stations northwest of South Georgia was significantly shallower than in other regions (Table 1; $48 \mathrm{~m}$ on average) and varied with proximity to the island, ranging from $\sim 9 \mathrm{~m}$ (closest inshore) to $97 \mathrm{~m}$ (most northerly station). Estimates of euphotic depth suggested that the depth of mixing exceeded the depth of light penetration away from fronts or coasts (Fig. 2).

\section{Total dissolvable iron and nutrient distribution}

Concentrations of total dissolvable iron (TD-Fe; includes dissolved and particulate iron which is leachable at $\mathrm{pH}$ 2) ranged from 0.89 to $13.6 \mathrm{nM}$. These values

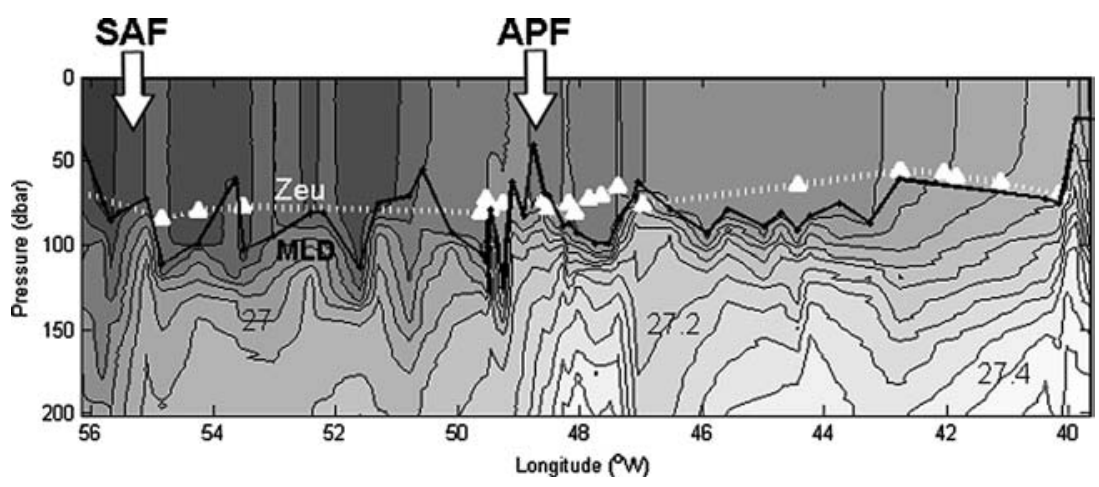



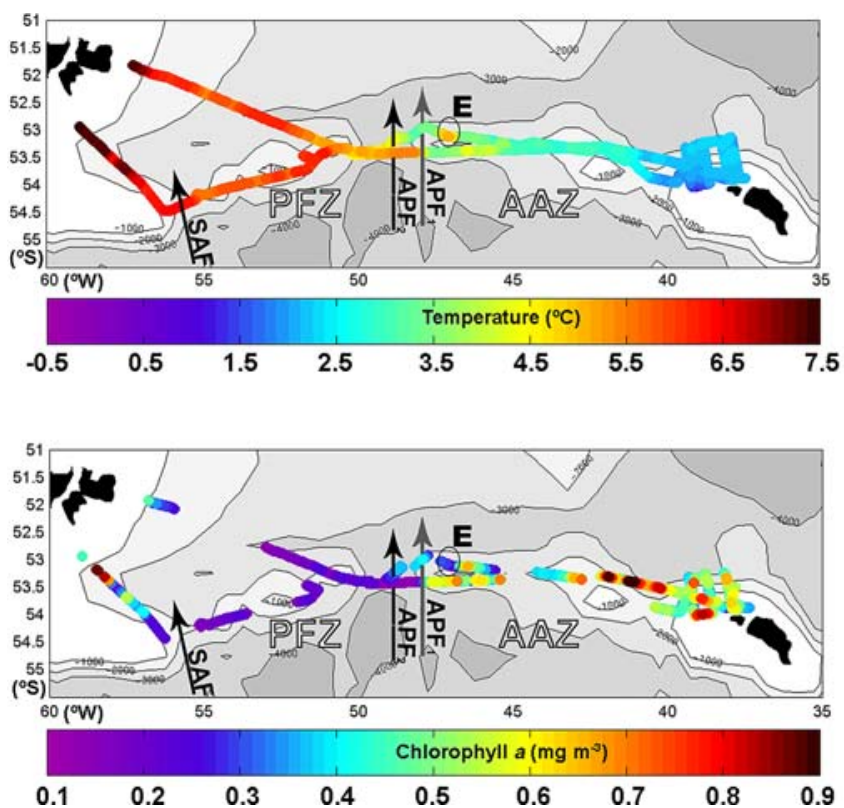

Fig. 3 Measurements of near surface $(6.5 \mathrm{~m})$ temperature, chlorophyll- $a$ and maximum photochemical quantum efficiency $\left(F_{\mathrm{v}} / F \mathrm{~m}\right)$ and surface concentrations of total dissolved iron, collected during JR-80. Arrows indicate the locations of the surface signatures of the Sub-Antarctic Front (SAF) and Antarctic Polar Front (APF) on transect 1 (grey) and 2 (black). Values of chlorophyll- $a$ (derived from HPLC chlorophyll- $a$ calibrated fluorescence) and $F_{\mathrm{v}} / F_{\mathrm{m}}$ represent dark-adapted measurements. An eddy-like structure within the Antarctic Zone (AAZ) with surface water similar to the Polar Frontal Zone (PFZ) is marked as "E". Isobaths are shown every $1,000 \mathrm{~m}$
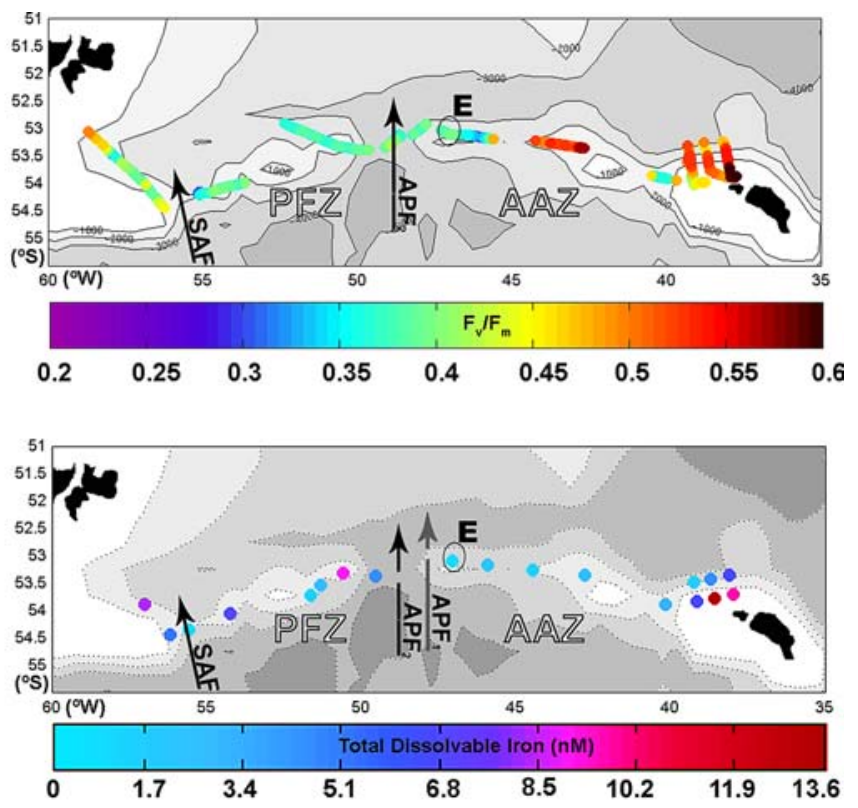

compare favourably to the dissolved $(<0.4 \mu \mathrm{m})$ fraction of iron measured by Blain et al. (2001) near the coast of Kerguelen. Their highest concentration $(12.6 \mathrm{nM}$, excluding the particulate phase) is slightly lower than our maximum value. TD-Fe concentrations were markedly higher in the samples collected at the South Georgia shelf (i.e., water depth $<200 \mathrm{~m}$ ) than throughout the rest of the region (Fig. 3). High TD-Fe in shallow water on the South Georgia shelf suggests a significant benthic iron source in this region.
Table 1 Statistical summary of mixed layer depth, euphotic zone, silicic acid concentration, phytoplankton

photophysiology $\left(F_{\mathrm{v}} / F_{\mathrm{m}}, \sigma_{\mathrm{PSII}}\right)$ and community structure index (fuco : hex). Means for the regions of the Polar Frontal Zone (PFZ), Antarctic Zone (AAZe, AAZw) and waters northwest of South Georgia (SG) appear in bold with standard deviations shown in italics; the number of data points appears in parentheses. Boxes separate means that are statistically different (at the 5\% level) based on a one-way ANOVA (*with the exception of groupings in fuco : hex, which was assessed using Mann-Whitney $U$ tests). The grey box indicates that this region was excluded from the statistical grouping because of extremely high variance in the mean

\begin{tabular}{|c|c|c|c|c|}
\hline $\begin{array}{l}\text { ZONE: } \\
\text { (apx. location) }\end{array}$ & $\begin{array}{c}\text { PFZ } \\
\left.\text { (54 to } 49^{\circ} \mathrm{W}\right)\end{array}$ & $\begin{array}{c}\text { AAZw } \\
\left(48 \text { to } 46^{\circ} \mathrm{W}\right)\end{array}$ & $\begin{array}{c}\text { AAZe } \\
\left(46 \text { to } 40^{\circ} \mathrm{W}\right)\end{array}$ & $\begin{array}{c}\text { SG } \\
\left(40 \text { to } 37^{\circ} \mathrm{W}\right)\end{array}$ \\
\hline $\begin{array}{l}\text { Mixed layer } \\
\text { depth }\end{array}$ & $\begin{array}{c}86.5 \pm 22.3 \\
(19) \\
\end{array}$ & $\begin{array}{c}90.1 \pm 7.36 \\
(7) \\
\end{array}$ & $\begin{array}{c}81.2 \pm 9.73 \\
(10) \\
\end{array}$ & $\begin{array}{c}48.1 \pm 26.9 \\
(11)\end{array}$ \\
\hline $\begin{array}{l}\text { Euphotic } \\
\text { depth }\end{array}$ & $\begin{array}{c}77.3 \pm 4.9 \\
(8) \\
\end{array}$ & $\begin{array}{c}73.3 \pm 5.8 \\
(5) \\
\end{array}$ & $\begin{array}{c}59.4 \pm 3.6 \\
(6) \\
\end{array}$ & $\begin{array}{c}61.3 \pm 6.6 \\
(8) \\
\end{array}$ \\
\hline Silicic acid & $\begin{array}{c}8.3 \pm 2.4 \\
(18) \\
\end{array}$ & $\begin{array}{c}20.0 \pm 2.3 \\
(6)\end{array}$ & $\begin{array}{c}20.5 \pm 3.7 \\
(12)\end{array}$ & $\begin{array}{c}30.32 \pm 2.13 \\
(8)\end{array}$ \\
\hline$F_{v} / F_{m}$ & $\begin{array}{c}0.37 \pm 0.03 \\
(167) \\
\end{array}$ & $\begin{array}{c}0.36 \pm 0.03 \\
(114) \\
\end{array}$ & $\begin{array}{c}0.51 \pm 0.03 \\
(75) \\
\end{array}$ & $\begin{array}{c}\mathbf{0 . 5 1} \pm 0.04 \\
(191) \\
\end{array}$ \\
\hline$\sigma_{P S \|}$ & $\begin{array}{c}1008.9 \pm 74.5 \\
(167) \\
\end{array}$ & $\begin{array}{c}960.9 \pm 52.9 \\
(114) \\
\end{array}$ & $\begin{array}{c}821.0 \pm 74.5 \\
(75)\end{array}$ & $\begin{array}{c}809.6 \pm 56.4 \\
(191) \\
\end{array}$ \\
\hline fuco:hex ${ }^{*}$ & $\begin{array}{c}0.74 \pm 0.28 \\
(7)\end{array}$ & $\begin{array}{c}1.38 \pm 0.50 \\
(6)\end{array}$ & $\begin{array}{c}1.85 \pm 0.28 \\
(6)\end{array}$ & $\begin{array}{c}2.43 \pm 0.92 \\
(7)\end{array}$ \\
\hline
\end{tabular}


Fig. 4 Longitudinal distribution of measurements from outward (triangles) and return (circles) legs of JR-80 (a) surface $F_{\mathrm{v}} / F_{\mathrm{m}}$ and $\sigma_{\mathrm{PSII}} ;(\mathbf{b})$ fuco : hex and surface silicic acid concentration. The location of surface signature of the Antarctic Polar Front (APF) is marked with a thick grey bar, separating measurements from the Polar Frontal Zone (PFZ) and the Antarctic Zone (AAZe and AAZw). An eddy-like structure within the AAZ with surface water similar to the PFZ is marked as "E". Measurements taken within approximately $50 \mathrm{~km}$ of the South Georgia shelf are labelled with "SG"
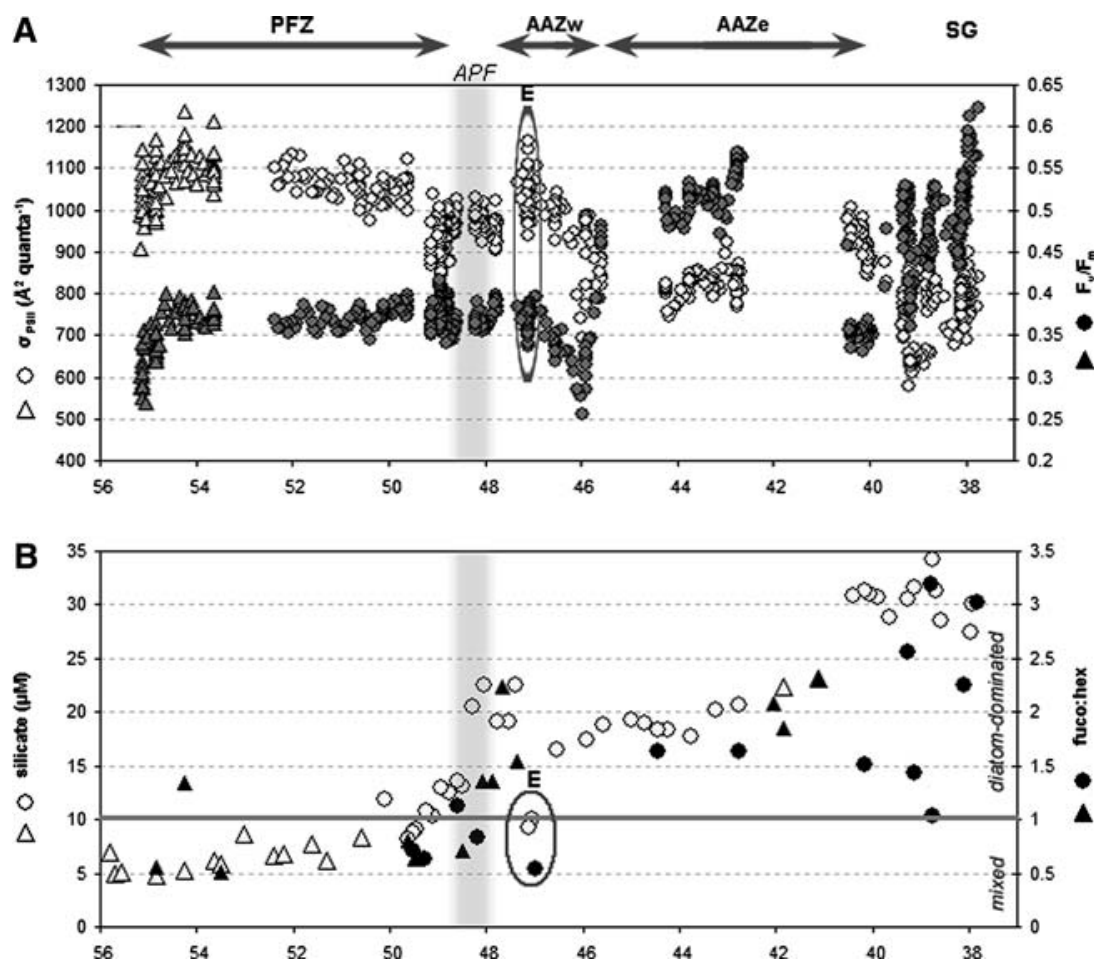

In general, concentrations of inorganic nutrients were the lowest at the western sites in the PFZ and increased in an easterly direction. Phosphate concentrations in the near surface $(6.5 \mathrm{~m})$ waters ranged from 1.44 (PFZ; station 6) to 1.99 (PFZ; station 12) $\mu \mathrm{mol} \mathrm{l}^{-1}$, and were the highest on average at the easterly stations. Nearsurface nitrate concentrations were high at all stations, ranging from 20.06 (PFZ; station 5) to 26.22 (WCB, water depth over $3,000 \mathrm{~m}) \mu \mathrm{mol} \mathrm{l}^{-1}$. Silicic acid concentrations ranged from 4.73 (PFZ; station 8) to 34.28 (WCB, water depth over $3,000 \mathrm{~m}$ ) $\mu \mathrm{mol} \mathrm{l}^{-1}$ (Fig. 4). A sharp gradient in surface concentrations of nitrate and silicic acid occurred in the region of the APF $\left(\mathrm{ca} 48^{\circ} \mathrm{W}\right)$ and east of $41^{\circ} \mathrm{W}$, near South Georgia. This gradient is evident in the differences between the mean silicic acid concentrations between regions (Table 1): concentration of silicic acid within the AAZ was significantly higher than the PFZ and significantly lower than concentrations northeast of South Georgia. There was no significant difference in silicic acid concentrations between the east and west AAZ.

Phytoplankton distribution and physiology

In nutritionally replete phytoplankton cells $F_{\mathrm{v}} / F_{\mathrm{m}}$ reaches a maximum value of 0.65 (Kolber and Falkowski 1993); values $<0.4$ have been taken to be indicative of iron-stressed phytoplankton in the Southern Ocean (Olson et al. 2000; Boyd and Abraham 2001; Gervais et al. 2002). $F_{\mathrm{v}} / F_{\mathrm{m}}$ was the highest near the shallow bathymetry of Shag Rocks and on the South Georgia shelf (Fig. 3), reaching values of 0.62 closest to
South Georgia. An increase in $F_{\mathrm{v}} / F_{\mathrm{m}}$ within the AAZ at $46^{\circ} \mathrm{W}$ separates two areas of significantly different physiology (Table 1$) . F_{\mathrm{v}} / F_{\mathrm{m}}$ was low to moderate $(0.25$ 0.42 ) in the PFZ and AAZw, but moderate to high $(0.45-0.57)$ east of $46^{\circ} \mathrm{W}$ in the AAZe and South Georgia regions. In general, there was an inverse relationship between the photosynthetic parameters, $F_{\mathrm{v}} / F_{\mathrm{m}}$ and $\sigma_{\mathrm{PSII}}$ (Fig. 4). Phytoplankton in the AAZe and near South Georgia (with high $F_{\mathrm{v}} / F_{\mathrm{m}}$ ) exhibited significantly lower $\sigma_{\mathrm{PSII}}$ than regions to the west (Table 1).

Near-surface phytoplankton pigment biomass, indicated by chlorophyll- $a$ concentrations derived from HPLC-calibrated night-time fluorescence (Fig. 3), was relatively low $\left(<0.25\right.$ mgchlorophyll- $\left.a \mathrm{~m}^{-3}\right)$ within the PFZ but exhibited a well-defined gradient across the APF ( $\sim 0.4 \mathrm{mg}$ chlorophyll- $a \mathrm{~m}^{-3}$ in $\left.30 \mathrm{~km}\right)$. Increased concentrations of chlorophyll- $a$ (up to 0.9 mgchlorophyll- $a \mathrm{~m}^{-3}$ ) were observed within the AAZ and near South Georgia. Light microscopy revealed that samples from the PFZ contained species of small diatoms (e.g., Pseudo-nitzschia spp.), but were dominated numerically by the flagellate, Phaeocystis antarctica. P. antarctica was also present in samples from the AAZ, but the diatoms Chaetoceros atlanticus, Chaetoceros dichaeta and Pseudo-nitzschia spp. were numerically dominant.

Characterization of community composition by accessory pigment distribution was consistent with the results of the microscopic analysis. Following the methods of Smith and Asper (2001), the ratio of fucoxanthin/19'-hexanoyloxyfucoxanthin (henceforth referred to as fuco : hex) was used as an indicator of the dominance of either diatoms or the prymnesiophyte, $P$. antarctica. There was a significant increase in fuco : 
hex in AAZ compared to the PFZ (Table 1). Pigment ratios suggested that there was a mixed assemblage $(1>$ fuco : hex $>0.2$ ) within the PFZ and diatom-dominance (fuco : hex $>1$ ) in the AAZ (Fig. 4). The changes in the fuco : hex ratio were due primarily to a threefold increase in fucoxanthin concentrations. Samples from the shelf waters of South Georgia showed extreme variability in the ratio of fuco : hex but contained the highest index of diatom-dominance.

Statistical analysis of fuco : hex distribution excluded samples from the SG region as the variance of fuco : hex within this region was significantly greater than other regions (i.e., the Levene statistic determined variances were significantly different at the $1 \%$ level). The fuco : hex from populations within the PFZ was significantly different from those in either AAZ region; the test did not detect a significant difference in fuco : hex within the east and west AAZ (Table 1).

A second proxy for prymnesiophyte dominance, the ratio of 19'-hexanoyloxyfucoxanthin/ chlorophyll-a (Jeffrey 1997), was consistent with the distribution patterns suggested by the fuco : hex ratio. It indicated that the contribution of prymnesiophytes to the species composition was highest in the PFZ. Concentrations of the accessory pigment, peridinin, indicative of autotrophic dinoflagellates (Jeffrey 1997) indicated that this functional group was absent from the majority of the transect, but was a minor component of phytoplankton populations at several stations in the relatively shallow waters near Shag Rocks and South Georgia. The presence of cryptophytes, indicated by detection of the accessory pigment alloxanthin (Jeffrey 1997), was limited to locations near South Georgia.

\section{Discussion}

The objective of our study of the North Scotia Ridge was to examine variability in phytoplankton photophysiology. The following discussion will investigate plausible sources of the variability in $F_{\mathrm{v}} / F_{\mathrm{m}}$ in an attempt to determine if it provides physiological support for the speculation that iron-limitation is alleviated in localized patches near pulse-point sources (i.e., bathymetric features) in this region.

Our measurements of photophysiology indicated significant differences in photosynthetic capacity across the study area (Table 1; Fig. 3). High values of $F_{\mathrm{v}} / F_{\mathrm{m}}$ $(>0.5)$ found to the east of Aurora Bank $\left(\sim 46^{\circ} \mathrm{W}\right)$ indicate that the majority of phytoplankton cells in these populations had high photosynthetic efficiency. This is physiological evidence that during our study populations downstream from a benthic point source of iron were growing in iron-replete conditions. The decreased $F_{\mathrm{v}} / F_{\mathrm{m}}$ in the AAZw and PFZ may be an indication of iron stress (Fig. 4). The transition in physiology between east and west AAZ suggest that during our study Aurora Bank marked the western extent of physiological influences of "pulse point" iron sources near South Georgia.
Observations of low $F_{\mathrm{v}} / F_{\mathrm{m}}$ and high $\sigma_{\mathrm{PSII}}$, suggestive of iron limitation (Boyd and Abraham 2001), extended throughout the AAZw and the PFZ. Photophysiology in these areas was in marked contrast to high $F_{\mathrm{v}} / F_{\mathrm{m}}$ and low $\sigma_{\mathrm{PSII}}$ in the AAZe. The largest gradient in photophysiology (between AAZw and AAZe) was located $\sim 200 \mathrm{~km}$ away from the APF. There were no marked changes in temperature, salinity or macronutrients coinciding with this gradient in photophysiology. Our data suggest that these regions of contrasting photophysiology also had significantly different light environments (Table 1). While differences in light environment may offer a partial explanation for differences in $\sigma_{\text {PSII }}$ (Dubinsky 1992), light is not thought to directly influence $F_{\mathrm{v}} / F_{\mathrm{m}}$ (Kolber et al. 1988).

Macronutrients were unlikely to be directly responsible for the broad-scale patterns in photophysiology. Nitrate-limitation can directly affect the function of photosynthetic machinery (Geider and LaRoche 1994) but was unlikely to be a factor driving the observed variation in $F_{\mathrm{v}} / F_{\mathrm{m}}$ since concentrations over the entire study area were high $\left(>20 \mu \mathrm{mol} \mathrm{l}^{-1}\right)$. In addition, although the largest gradient in macronutrients coincided with the APF, there was no significant change in $F_{\mathrm{v}} / F_{\mathrm{m}}$ between the regions on either side (Table 1). Where differences in $F_{\mathrm{v}} / F_{\mathrm{m}}$ were found $(200 \mathrm{~km}$ away), they separated regions with similar macronutrient concentration. It is possible, nevertheless, that silicic acid might have driven shifts in community structure, since concentrations range from potentially limiting for diatom growth (Nelson et al. 2001) in the west where flagellates dominated the phytoplankton population, to silicic acidreplete in the east where the population was diatom dominated. Consequently, any inherent taxonomic variation in $F_{\mathrm{v}} / F_{\mathrm{m}}$ (Moore et al. 2005) could potentially contribute to the observed variation in photophysiology due to silicic acid limitation of diatom growth.

The contrast in silicic acid concentrations between the AAZw and the PFZ observed in our study is a welldocumented feature of the ACC (Nelson et al. 2001; Pollard et al. 2002) and has been shown to accompany a shift in community composition from diatoms to flagellates in other areas of the ACC (Mengelt et al. 2001; Smetacek et al. 2002), consistent with our data (Table 1).

Variations in phytoplankton community structure between the PFZ and the AAZ were thus large relative to variations within the AAZ. Conversely, variability of $F_{\mathrm{v}} / F_{\mathrm{m}}$ and $\sigma_{\mathrm{PSII}}$ was higher within the AAZ than between the PFZ and AAZe. Thus, although we cannot rule out the possibility that species composition affected our measures of bulk community photophysiology, another factor was likely to have been responsible for the observed shift in physiology between the AAZw and AAZe.

In contrast to direct control by macronutrients or the indirect influences of taxonomy, we return to iron availability as a factor governing the observed gradients in $F_{\mathrm{v}} / F_{\mathrm{m}}$ and $\sigma_{\mathrm{PSII}}$. The passage of the currents 
over continental shelves and shallow bathymetry is likely to supply coastal waters with sedimentary sources of iron, which may subsequently be transported into the open ocean where it is gradually removed through biological uptake (Löscher et al. 1997). The theory that the interaction of currents with topographic features around South Georgia may deliver sediment derived iron to nearby downstream areas is not novel. Korb and Whitehouse (2004) propose that an increase in iron-availability downstream (i.e., northwest) of South Georgia was responsible for the contrast between the high and low production regimes they observed there.

Similarly, we suggest that the contrast between our measurements of $F_{\mathrm{v}} / F_{\mathrm{m}}$ and $\sigma_{\text {PSII }}$ in populations east and west of $46^{\circ} \mathrm{W}$ along the North Scotia Ridge represented a transition from iron-replete to iron-limited populations. Waters to the east of $46^{\circ} \mathrm{W}$ (AAZe) were likely downstream from a benthic source around South Georgia while bioavailable iron was potentially lower in waters to the west (AAZw) due to less sediment interaction. It is important to recognize that our measurements of TD-Fe represent the sum of both the particulate and dissolved fractions of iron, of which only a small percentage is likely to be bioavailable. Only the small colloidal and truly dissolved forms of iron are known to be assimilated by the biological pool (Sunda 2001). Further work assessing changes in phytoplankton physiology, concurrent with measures of the bioavailable iron pools, would clearly be advantageous in elucidating how current interactions with bathymetry control phytoplankton productivity in this region.

\section{Conclusions}

Our observations of high values $(>0.5)$ of $F_{\mathrm{v}} / F_{\mathrm{m}}$ along the North Scotia Ridge in the AAZ northwest of South Georgia and high TD-Fe over shallow bathymetry near South Georgia provide strong support for the hypothesis that there are "pulse-point" sources of benthic iron in this region. High $F_{\mathrm{v}} / F_{\mathrm{m}}$ indicated an absence of the physiological symptoms of iron-stress suggesting growth in iron-replete conditions. A large east-west gradient in photosynthetic capacity (i.e., $F_{\mathrm{v}} / F_{\mathrm{m}}$ ) could not be explained by changes in other properties such as nitrate, silicic acid or taxonomic composition. We suggest that the variation in photophysiology was the result of differences in the availability of iron.

Acknowledgements Our thanks to Inga Smith, Louise Sime and Mike Meredith for their assistance in supplying and interpreting data. We also thank the officers and crew of the RRS James Clark Ross for their help and hard work during JR80. This work was supported by the University of Southampton and by the NERC AFI programme through grant number NER/G/S/2001/00006. We would like to thank Stephanie Henson and two anonymous reviewers for their comments and suggestions on earlier versions of the manuscript.

\section{References}

Barlow RG, Mantoura R, Gough MA, Fileman TW (1993) Pigment signatures of the phytoplankton composition in the northeastern Atlantic during the 1990 spring bloom. Deep-Sea Res II-Top Stud Oceanogr 40:459-477

Behrenfeld MJ, Bale A, Kolber Z, Aiken J, Falkowski P (1996) Confirmation of iron limitation of phytoplankton photosynthesis in the equatorial Pacific Ocean. Nature 383:508-511

Blain S, Treguer P, Belviso S, Bucciarelli E, Denis M, Desabre S, Fiala M, Jezequel VM, Le Fevre J, Mayzaud P, Marty JC, Razouls S (2001) A biogeochemical study of the island mass effect in the context of the iron hypothesis: Kerguelen Islands, Southern Ocean. Deep-Sea Res I-Oceanogr Res Pap 48:163187

Boyd PW (2002) Environmental factors controlling phytoplankton processes in the Southern Ocean. J Phycol 38:844-861

Boyd PW, Abraham ER (2001) Iron-mediated changes in phytoplankton photosynthetic competence during SOIREE. DeepSea Res II-Top Stud Oceanogr 48:2529-2550

Boyd PW, Watson AJ, Law CS, Abraham ER, Trull T, Murdoch R, Bakker D, Bowie AR, Buesseler KO, Chang H, Charette M, Croot P, Downing K, Frew R, Gall M, Hadfield M, Hall J, Harvey M, Jameson G, LaRoche (2000) A mesoscale phytoplankton bloom in the polar Southern Ocean stimulated by iron fertilization. Nature 407:695-702

Coale KH, Johnson KS, Chavez FP, Buesseler KO, Barber RT, Brzezinski MA, Cochlan WP, Millero FJ, Falkowski PG, Bauer JE, Wanninkhof RH, Kudela RM, Altabet MA, Hales BE, Takahashi T, Landry MR, Bidigare RR, Wang X, Chase Z, Strutton PG, Friederich GE, Gorbunov MY, Lance VP, Hilting AK, Hiscock MR, Demarest M, Hiscock WT, Sullivan KF, Tanner SJ, Gordon RM, Hunter CN, Elrod VA, Fitzwater SE, Jones JL, Tozzi S, Koblizek M, Roberts AE, Herndon J, Brewster J, Ladizinsky N, Smith G, Cooper D, Timothy D, Brown SL, Selph KE, Sheridan CC, Twining BS, Johnson ZI (2004) Southern Ocean iron enrichment experiment: carbon cycling in high- and low-Si waters. Science 304:408-414

Comiso JC, McClain CR, Sullivan CW, Ryan JP, Leonard CL (1993) Coastal zone color scanner pigment concentrations in the Southern Ocean and relationships to geophysical surface features. J Geophys Res-Oceans 98:2419-2451

Cooper DJ, Watson AJ, Nightingale PD (1996) Large decrease in ocean-surface $\mathrm{CO}_{2}$ fugacity in response to in situ iron fertisation. Nature 383:511-513

De Baar HJW, Buma AGJ, Nolting RF, Cadee GC, Jacques G, Treguer PJ (1990) On iron limitation of the Southern Ocean: experimental observations in the Weddell and Scotia Seas. Mar Ecol Prog Ser 65:105-122

Dubinsky Z (1992) The functional and optical absorption cross sections of phytoplankton photosynthesis. In: Falkowski P, Woodhead AD (eds) Primary productivity and biogeochemical cycles in the sea. Plenum Press, New York, pp 31-45

Frost B (1991) The role of grazing in nutrient-rich areas of the open ocean. Limnol Oceanogr 36:1616-1630

Geider R, LaRoche J (1994) The role of iron in phytoplankton photosynthesis, and the potential for iron-limitation of primary production in the sea. Photosynth Res 39:275-301

Gervais F, Riebesell U, Gorbunov MY (2002) Changes in primary productivity and chlorophyll a in response to iron fertilization in the Southern Polar Frontal Zone. Limnol Oceanogr 47:1324 1335

Gill AE (1981) Atmosphere-ocean dynamics. Academic, New York, 662pp

Gordon AL, Georgi DT, Taylor HW (1977) Antarctic Polar Front Zone in the Western Scotia Sea-summer 1975. J Phys Oceanogr 7:309-328

Greene RM, Geider RJ, Falkowski PG (1991) Effect of iron limitation on photosynthesis in a marine diatom. Limnol Oceanogr 36:1772-1782 
Holm-Hansen O, Naganobu M, Kawaguchi S, Kameda $T$, Krasovski I, Tchernyshkov P, Priddle J, Korb R, Brandon M, Demer D, Hewitt RP, Kahru M, Hewes CD (2004) Factors influencing the distribution, biomass, and productivity of phytoplankton in the Scotia Sea and adjoining waters. Deep-Sea Res II-Top Stud Oceanogr 51:1333-1350

Jeffrey SW (1997) Application of pigment methods to oceanography. In: Jeffrey SW, Mantoura RFC, Wright SW (eds) Phytoplankton pigments in oceanography. UNESCO, Paris, pp 661

Johnson KS, Elrod VA, Fitzwater SE, Plant JN, Chavez FP, Tanner SJ, Gordon RM, Westphal DL, Perry KD, Wu J, Karl DM (2003) Surface ocean-lower atmosphere interactions in the Northeast Pacific Ocean Gyre: aerosols, iron, and the ecosystem response. Global Biogeochem Cycles 17(2):32

Kolber Z, Falkowski P (1993) Use of active fluorescence to estimate phytoplankton photosynthesis in situ. Limnol Oceanogr 38:1646-1665

Kolber Z, Zehr J, Falkowski P (1988) Effects of growth irrandiance and nitrogen limitation on photosynthetic energy-conversion in photosystem-II. Plant Physiol 88:923-929

Kolber Z, Prasil O, Falkowski P (1998) Measurements of variable chlorophyll fluorescence using fast repetition rate techniques: defining methodology and experimental protocols. Biochim Biophys Acta 1367:88-106

Korb RE, Whitehouse MJ (2004) Contrasting primary production regimes around South Georgia, Southern Ocean: large blooms versus high nutrient, low chlorophyll waters. Deep-Sea Res I-Oceanogr Res Pap 51:721-738

Landing WM, Haraldsson C, Paxeus N (1986) Vinyl polymer agglomerate based transition metal cation chelating ion-exchange resin containing the 8-hydroxyquinoline functional group. Anal Chem 58(14):3031-3035

Laney SR (2003) Assessing the error in photosynthetic properties determined by fast repetition rate fluorometry. Limnol Oceanogr 48:2234-2242

Lindley S, Barber RT (1998) Phytoplankton response to natural and experimental iron addition. Deep-Sea Res II-Top Stud Oceanogr 45:1135-1149

Löscher B, DeBaar H, DeJong J, Veth C, Dehairs F (1997) The distribution of Fe in the Antarctic Circumpolar Current. DeepSea Res II-Top Stud Oceanogr 44:143-187

Martin JH (1990) Glacial-interglacial $\mathrm{CO}_{2}$ change: the iron hypothesis. Paleoceanography 5:1-13

Mengelt C, Abbott MR, Barth JA, Letelier RM, Measures CI, Vink S (2001) Phytoplankton pigment distribution in relation to silicic acid, iron and the physical structure across the Antarctic Polar Front, 170 degrees W, during austral summer. Deep-Sea Res II-Top Stud Oceanogr 48:4081-4100

Meredith MP, Watkins JL, Murphy EJ, Cunningham NJ, Wood AG, Korb R, Whitehouse MJ, Thorpe SE (2003) An anticyclonic circulation above the Northwest Georgia Rise, Southern Ocean. Geophys Res Lett 30(20):2061 (doi:10.1029/ 2003GL018039)

Moore JK, Abbott MR (2002) Surface chlorophyll concentrations in relation to the Antarctic Polar Front: seasonal and spatial patterns from satellite observations. J Mar Syst 37:69-86

Moore JK, Abbott MR, Richman JG (1999) Location and dynamics of the Antarctic Polar Front from satellite sea surface temperature data. J Geophys Res 104:3059-3073

Moore CM, Lucas MI, Sanders R, Davidson R (2005) Basin-scale variability of phytoplankton bio-optical characteristics in relation to bloom state and community structure in the Northeast Atlantic. Deep-Sea Res I-Oceanogr Res Pap 52:401-419

Nelson DM, Smith WO (1991) Sverdrup revisited - critical depths, maximum chlorophyll levels, and the control of SouthernOcean productivity by the irradiance-mixing regime. Limnol Oceanogr 36:1650-1661

Nelson DM, Brzezinski MA, Sigmon DE, Franck VM (2001) A seasonal progression of $\mathrm{Si}$ limitation in the Pacific sector of the
Southern Ocean. Deep-Sea Res II-Top Stud Oceanogr 48:3973-3995

Obata H, Karatani H, Nakayama E (1993) Automated determination of iron in seawater by chelating resin concentration and chemiluminescence detection. Anal Chem 65:1524-1528

Olson RJ, Sosik HM, Chekalyuk AM, Shalapyonok A (2000) Effects of iron enrichment on phytoplankton in the Southern Ocean during late summer: active fluorescence and flow cytometric analyses. Deep-Sea Res II-Top Stud Oceanogr 47:3181-3200

Orsi A, Whitworth T III, Nowlin W Jr (1995) On the meridional extent and fronts of the Antarctic Circumpolar Current. DeepSea Res I-Oceanogr Res Pap 5:641-673

Pollard RT, Lucas MI, Read JF (2002) Physical controls on biogeochemical zonation in the Southern Ocean. Deep-Sea Res II-Top Stud Oceanogr 49:3289-3305

Priddle J, Smetacek V, Bathmann U (1992) Antarctic marine primary production, biogeochemical cycles and climate change. Philos Trans R Soc Lond Ser B-Biol Sci 338:289-297

Raven JA (1990) Predictions of $\mathrm{Mn}$ and $\mathrm{Fe}$ use efficiencies of phototrophic growth as a function of light availability for growth and C assimilation pathway. New Phytol 116:1-18

Sanders R, Jickells T (2000) Total organic nutrients in Drake Passage. Deep-Sea Res I-Oceanogr Res Pap 47(6):997-1014

Sherrell RM, Boyle EA (1988). Zinc, chromium, vanadium and iron in the Mediterranean Sea. Deep-Sea Res I-Oceanogr Res Pap 35:1319-1334

Smetacek F, Scharek R, Nothig E-M (1990) Seasonal and regional variation in the pelagial and its relationship to the life history cycle of krill. In: Kerry KR, Hempel G (ed) Antarctic ecosystems: ecological change and conservation. Springer, Berlin Heidelberg, New York, pp 103-114

Smetacek V, Klaas C, Menden-Deuer S, Rynearson TA (2002) Mesoscale distribution of dominant diatom species relative to the hydrographical field along the Antarctic Polar Front. DeepSea Res II-Top Stud Oceanogr 49:3835-3848

Smith WO Jr, Asper VL (2001) The influence of phytoplankton assemblage composition on biogeochemical characteristics and cycles in the southern Ross Sea, Antarctica. Deep-Sea Res I-Oceanogr Res Pap 48:137-161

Suggett DJ, MacIntyre HL, Geider RJ (2004) Evaluation of biophysical and optical determinations of light absorption by photosystem II in phytoplankton. Limnol Oceanogr: Methods $2: 316-332$

Sullivan CW, Arrigo KR, McClain CR, Comiso JC, Firestone J (1993) Distributions of phytoplankton blooms in the Southern Ocean. Science 262:1832-1837

Sunda WG (2001) Bioavailability and Bioaccumulation of Iron in the Sea. In: Turner DR, Hunter KA (eds) Biogeochemistry of iron in seawater. Wiley, Chichester, pp 41-84

Sunda WG, Huntsman SA (1997) Interrelated influence of iron, light and cell size on marine phytoplankton growth. Nature 390:389-392

Thorpe SE (2001) Variability of the Southern Antarctic Circumpolar Current in the Scotia Sea and its implications for transport to South Georgia. Ph.D. thesis, University of East Anglia, Norwich, UK, 212pp

Thorpe SE, Heywood KJ, Brandon MA, Stevens DP (2002) Variability of the southern Antarctic Circumpolar Current front north of South Georgia. J Mar Syst 37:87-105

Timmermans KR, Davey MS, van der Wagt B, Snoek J, Geider RJ, Veldhuis M, Gerringa L, de Baar H (2001) Co-limitation by iron and light of Chaetoceros brevis, C. dichaeta and C.calcitrans (Bacillariophyceae). Mar Ecol-Prog Ser 217:287-297

Watson AJ, Bakker D, Ridgwell AJ, Boyd PW, Law CS (2000) Effect of iron supply on Southern Ocean $\mathrm{CO}_{2}$ uptake and implications for glacial atmospheric $\mathrm{CO}_{2}$. Nature 407:730-733 